Revista Eletrônica Geografar, Curitiba, v. 2, Resumos do VI Seminário Interno de Pós-Graduação em Geografia, p. 56-56. Junho/2007

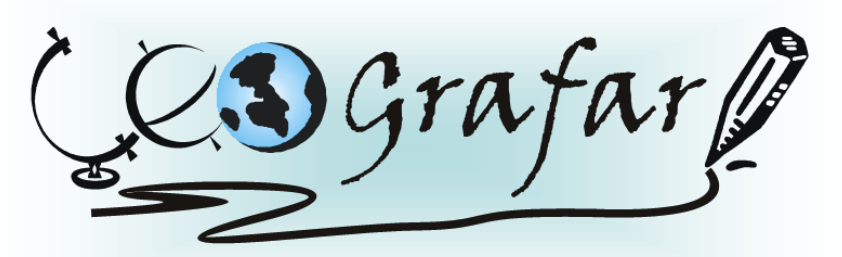

Revista Eletrônica do Programa de Pós-Graduação em Geografia - UFPR

\title{
IMAGEM TURÍSTICA DE CALMON E MATOS COSTA (SC) ATINENTE À GUERRA DO CONTESTADO SOB A ÓTICA DE SEUS MORADORES E TURISTAS
}

\author{
MICHELE APARECIDA HOBAL ${ }^{1}$
}

O turismo é visto, em muitos casos, como fator de desenvolvimento econômico de uma região. Entretanto, como o turismo é tanto uma atividade econômica como social, pode também assumir a função de conscientizar e educar. Neste sentido, ter seu foco sobre os próprios recursos de uma região, como natureza, cultura, história e sociologia, sendo estes os elementos vividos e memorizados pela população local, como também elementos dos cenários para os turistas. Assim, a existência da atividade turística pode apresentar uma possibilidade, entre outras, da monumentalização da história regional e da conscientização das condições sociais, num processo de formação socio-espacial da região, gerenciado na comunicação entre pessoas moradores e turistas. Neste contexto, o turismo participa da discussão da questão cultural permitindo o desenvolvimento de uma sociedade regional, uma vez que proporciona uma interação cultural entre turistas e receptores locais. $\mathrm{O}$ presente projeto consiste em analisar a função das imagens turísticas da Guerra do Contestado na transformação das cidades de Calmon e Matos Costa, Estado de Santa Catarina, e pretende analisar como as suas respectivas populações foram incluídas ou excluídas nos acontecimentos do Contestado (1912-1916) e como os seus descendentes se posicionam hoje em relação a estes eventos. O trabalho objetiva pesquisar qual é a função do turismo neste processo de apropriação e/ou alienação dos moradores da sua própria história e em que forma isto se reproduz através de suas representações sociais. Procura-se, assim, avaliar uma imagem turística desta fase histórica nas duas cidades que permita a comunicação livre e democrática sobre estes eventos traumáticos do passado.

PALAVRAS - CHAVE: Turismo e Percepção, Representações Sociais, Calmon e Matos Costa na Guerra do Contestado.

'Doutoranda em Geografia - UFPR - email: michelehobal@hotmail.com Orientador: WOLF DIETRICH SAHR 